\title{
Analisis Kesulitan Siswa dalam Menyelesaikan Soal Hukum Newton
}

\author{
Muh. Rozaqul Fadlli ${ }^{1}$, Sutopo ${ }^{1}$, Wartono ${ }^{1}$ \\ ${ }^{1}$ Pendidikan Fisika-Universitas Negeri Malang
}

\begin{tabular}{l}
\hline \hline INFO ARTIKEL \\
\hline Riwayat Artikel: \\
Diterima: $19-03-2019$ \\
Disetujui: 12-08-2019 \\
\hline
\end{tabular}

\section{Kata kunci:}

analysis of student difficulties; Newton's Law; analisis kesulitan siswa; hukum newton

\begin{abstract}
ABSTRAK
Abstract: This study aims to determine the difficulties students have in Newton's Law. The research method used is descriptive qualitative. The subject of this study was the X MIPA which amounted to 102 students. Data collection is done by giving multiple choice reasoned and interviews. The analysis using descriptive percentages. Tests for Newton's Law consist of 3 items. The problem used in this study is the inertia of objects, identifying the forces acting on falling objects and the large force of interaction between two objects. The results showed that students' understanding of the three questions included the low category. Students are still having difficulty in understanding the inertia of objects, still having difficulty in identifying any style that works on falling objects and also students still cannot determine the style of interaction between two objects.
\end{abstract}

\begin{abstract}
Abstrak: Tujuan dalam penulisan artikel ini untuk mengetahui kesulitan yang dimiliki siswa pada materi Hukum Newton. Penelitian ini menggunakan metode kualitatif deskriptif. Subjek yang digunakan dalam penelitian ini kelas X MIPA yang berjumlah 102 siswa. Pengambilan data dilakukan dengan pemberian soal pilihan ganda beralasan dan wawancara. Analisis dilakukan dengan menggunakan deskriptif persentase. Tes materi hukum newton terdiri dari tiga butir soal. Dalam penelitian ini soal yang digunakan adalah kelembaman pada benda, mengidentifikasi gaya yang bekerja pada benda jatuh dan besar gaya interaksi antara dua benda. Hasil penelitian menunjukkan pemahaman siswa pada ketiga soal termasuk kategori rendah. Siswa masih kesulitan dalam memaknai kelembaman pada benda, kesulitan dalam identifikasi gaya apa saja yang bekerja pada benda jatuh dan juga siswa masih belum bisa menentukan besar gaya interaksi antara dua benda.
\end{abstract}

\author{
Alamat Korespondensi: \\ Muh. Rozaqul Fadlli \\ Pendidikan Fisika \\ Universitas Negeri Malang \\ Jalan Semarang 5 Malang \\ E-mail: muh.rozaqul.1703218@students.um.ac.id
}

Hukum Newton merupakan salah satu hukum fundamental dalam fisika. Hukum Newton dapat menjelaskan fenomena yang berkaitan dengan gerak (Astrina, Sahala, \& Oktavianty, 2014). Hukum Newton membahas hubungan antara massa, percepatan, dan gaya yang bekerja pada benda (Halliday, Resnick, Krane, \& Stanley, 2001; Serway \& Jewett, 2006). Oleh karena itu, siswa perlu dengan baik memahami materi hukum newton. Namun kenyataannya, siswa mengalami kesulitan menerapkan hukum Newton untuk menyelesaikan permasalahan (Kaddari, Elachqar, \& Alami, 2014; Kim \& Pak, 2002; Savinainen \& Scott, 2002; Smith \& Wittmann, 2007). Berdasarkan penelitian yang dilakukan oleh (Palmer, 2001) di Australia Selatan, siswa masih kesulitan mengidentifikasi gaya pada benda ketika benda dilempar vertikal ke atas dan penelitian yang dilakukan oleh (Smith \& Wittmann, 2007) di Amerika siswa masih mengalami kesalahan menentukan besar gaya interaksi antara dua benda yang berbeda massa. Kesulitan lain yang dialami siswa pada materi Hukum II Newton adalah mengaitkan resultan gaya, kecepatan dan percepatan (Rosenblatt \& Heckler, 2011), menentukan komponen resultan gaya (Singh \& Schunn, 2016), membuat diagram benda bebas untuk memecahkan masalah terkait hukum II Newton (Heckler, 2010; Rosengrant, Van Heuvelen, \& Etkina, 2009; Savinainen, Mäkynen, Nieminen, \& Viiri, 2013). Siswa juga kesulitan pada Hukum III Newton dalam memahami interaksi antara dua benda (Savinainen, Mäkynen, Nieminen, \& Viiri, 2012; Sayre, Franklin, Dymek, Clark, \& Sun, 2012). Kesulitan-kesulitan tersebut terjadi karena pengalaman empiris siswa yang berbeda dan kesulitan dalam mendeskripsikan fenomena kemudian membawanya ke dalam konsep fisika (Elmehdi, Pistorius, \& Suleiman, 2013).

Sehubungan masih banyaknya kesulitan yang dialami siswa dalam mengidentifikasi gaya yang bekerja pada benda dan memahami interaksi antara dua benda pada Hukum III Newton baik penelitian di dalam negeri maupun luar negeri maka peneliti akan menganalisis kesulitan siswa dalam mengidentifikasi gaya yang bekerja pada benda dan Hukum III Newton di salah satu SMA di kota Malang. Selanjutnya, diupayakan alternatif solusinya sehingga kesulitan yang dialami tidak terulang kembali dan dapat digunakan untuk merancang pembelajaran sehingga kualitas hasil belajar siswa dapat meningkat. 


\section{METODE}

Analisis dalam penelitian ini menggunakan analisis deskriptif kualitatif dengan mendeskriptifkan kesulitan siswa dalam penyelesaian soal dan menganalisis penyebab kesalahan jawaban pada materi hukum newton. Penelitian ini dilakukan di salah satu SMA di kota Malang dengan subjek penelitian berjumlah 102 siswa kelas X MIPA yang telah mempelajari Hukum Newton.

Pengumpulan sampel penelitian berupa tes pilihan ganda beralasan dan wawancara. Tes pilihan ganda digunakan untuk mengetahui kesulitan siswa dalam menyelesaikan soal, sedangkan hasil alasan siswa digunakan untuk mengetahui alasan siswa menjawab soal. Wawancara dilakukan kepada guru dan siswa. Data wawancara pada siswa digunakan sebagai data pendukung dan memperkuat data setelah siswa mengerjakan tes. Sedangkan data wawancara kepada guru untuk mengetahui kesulitan yang sering terjadi saat mempelajari hukum newton. Materi hukum newton yang diujikan dikelompokkan menjadi tiga sub-topik, yaitu Hukum I Newton, Gaya yang bekerja pada Benda, dan Hukum III Newton.

Pada penelitian ini, teknik analisis data yang digunakan adalah analisis deskriptif kualitatif. Langkah awal sebelum dilakukan penelitian yaitu membuat kisi-kisi soal disertai rambu jawaban berdasarkan indikator yang telah ditentukan. Kemudian mengklasifikasikan jawaban siswa berdasarkan kesamaan jawaban.

\section{HASIL}

\section{Hukum I Newton}

Untuk mengetahui kesulitan siswa dalam mengerjakan Hukum I Newton, siswa diberikan soal pada gambar 1. Soal berisi tentang seseorang yang berdiri di dalam bus, kemudian bus tiba-tiba berhenti. Selanjutnya, siswa diberikan pertanyaan kenapa tubuh orang tersebut bergerak ke depan. Hasil jawaban siswa disajikan pada tabel 1.

Amir berdiri di dalam bus, kemudian tiba-tiba bus di rem mendadak sehingga Amir terdorong ke depan.

Terdorongnya Amir ke depan karena

a. karena mendapatkan gaya dorong dari bus ke arah depan

b. karena memiliki kecepatan ke depan terhadap bumi

c. karena gaya tarik oleh bumi

\section{Gambar 1. Soal Hukum I Newton}

Tabel 1. Hasil Jawaban Siswa pada Hukum I Newton

\begin{tabular}{ccc}
\hline \multicolumn{2}{c}{ Jawaban } & Persentase (\%) \\
\hline Benar & B & 14,7 \\
\hline Salah & A & 79,4 \\
\hline & C & 5,88
\end{tabular}

Berdasarkan tabel 1. diperoleh persentase jawaban benar cukup rendah jika dibandingkan dengan hasil persentase jawaban yang salah. Hal tersebut menunjukkan bahwa siswa masih mengalami kesulitan untuk mengerjakan soal Hukum I Newton.

\section{Gaya pada Gerak Vertikal}

Untuk mengetahui kesulitan siswa dalam mengerjakan soal gaya yang bekerja pada suatu benda siswa diukur melalui soal pada gambar 2. Soal berisi seorang anak yang melempar bola karet ke atas dan sampai sebelum bola karet menyentuh lantai. Kemudian siswa ditanya gaya yang bekerja pada bola karet selama di udara. Hasil jawaban siswa dapat dilihat pada tabel 2. Berdasarkan tabel 2, diperoleh persentase jawaban benar cukup rendah jika dibandingkan dengan jawaban salah. Hal tersebut menunjukkan bahwa siswa masih kesulitan dalam mengidentifikasi gaya vertikal.

\section{Tabel 2. Hasil Persentase Jawaban Siswa}

\begin{tabular}{ccc}
\hline \multicolumn{2}{c}{ Jawaban } & Persentase (\%) \\
\hline Benar & D & 0 \\
\hline Salah & B & 60,8 \\
\hline & C & 38,2 \\
\hline
\end{tabular}


Seorang anak berada di atas gedung kemudian melempar bola karet ke atas. Cermati gerak bola setelah lepas dari tangan dan sebelum mencapai tanah, gaya gesek udara sangat kecil sehingga bisa diabaikan. Untuk kondisi ini, gaya yang bekerja pada bola adalah...

a. Gaya gravitasi ke bawah bersamaan dengan gaya ke atas yang berkurang secara beraturan

b. Gaya ke atas yang berkurang secara beraturan sampai titik tertinggi, ketika bola bergerak ke bawah, gaya gravitasi ke bawah yang bertambah secara beraturan.

c. Ketika bola naik hingga titik tertinggi, bekerja gaya pelempar ke atas yang berkurang secara beraturan dan gaya gravitasi yang hampir konstan; Ketika bola turun hingga mencapai tanah, hanya bekerja gaya gravitasi yang hampir konstan

d. Hanya bekerja gaya gravitasi yang besarnya konstan ke bawah

e. Semua jawaban salah. Bola jatuh ke tanah karena kecenderungan alamiahnya diam di atas permukaan tanah

\section{Gambar 2. Soal Gaya yang Bekerja pada Benda}

\section{Hukum III Newton}

Untuk mengetahui kesulitan yang dimiliki siswa dalam menyelesaikan soal Hukum III Newton siswa diukur melalui soal pada gambar 3. Soal berisi sedan yang sedang menarik truk. Hasil jawaban siswa dapat dilihat pada tabel 3. Berdasarkan tabel 3, diperoleh persentase jawaban benar siswa lebih rendah jika dibandingkan dengan jawaban salah. Hal tersebut menunjukkan bahwa siswa masih mengalami kesulitan dalam mengerjakan soal hukum III Newton.

\section{Tabel 3. Hasil Persentase Jawaban Siswa pada Hukum III Newton}

\begin{tabular}{ccc}
\hline \multicolumn{2}{c}{ Jawaban } & Persentase (\%) \\
\hline Benar & A & 5,8 \\
\hline Salah & B & 18,6 \\
\hline & C & 51 \\
\hline & D & 24,5 \\
\hline
\end{tabular}

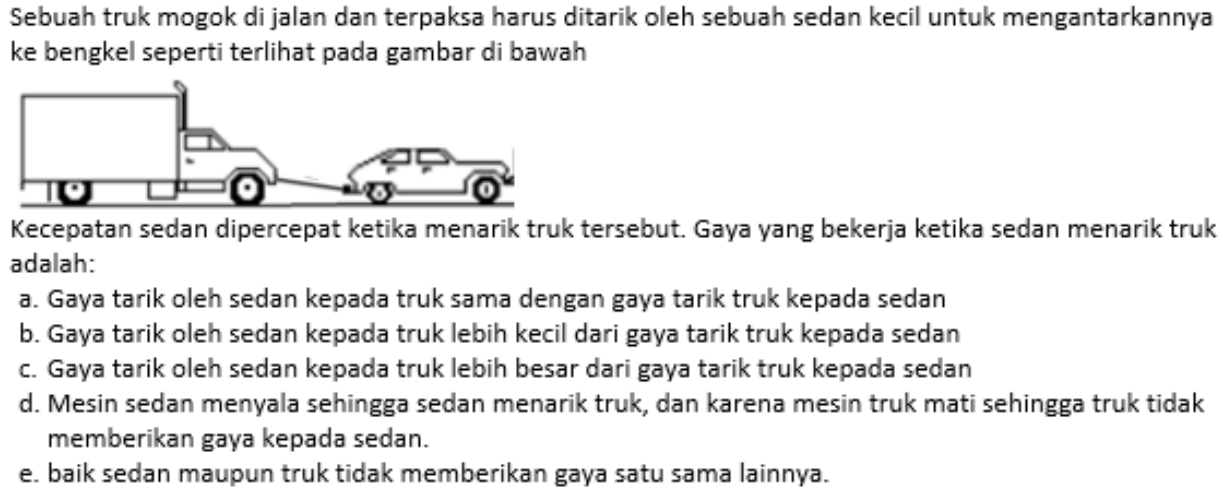

Kecepatan sedan dipercepat ketika menarik truk tersebut. Gaya yang bekerja ketika sedan menarik truk adalah:

a. Gaya tarik oleh sedan kepada truk sama dengan gaya tarik truk kepada sedan

b. Gaya tarik oleh sedan kepada truk lebih kecil dari gaya tarik truk kepada sedan

c. Gaya tarik oleh sedan kepada truk lebih besar dari gaya tarik truk kepada sedan

d. Mesin sedan menyala sehingga sedan menarik truk, dan karena mesin truk mati sehingga truk tidak memberikan gaya kepada sedan.

e. baik sedan maupun truk tidak memberikan gaya satu sama lainnya.

\section{Gambar 3. Soal Hukum III Newton}

\section{PEMBAHASAN}

\section{Hukum I Newton}

Siswa harus memahami "Jika resultan gaya pada benda bernilai nol, maka benda diam akan tetap diam atau benda bergerak akan tetap bergerak lurus dengan percepatan nol". Dalam soal Hukum I Newton, Amir berada di dalam bus dan bus mendadak berhenti. Kemudian ditanyakan alasan terdorongnya amir ke depan. Hasil tes Hukum I Newton disajikan pada Tabel 1. Berdasarkan tabel 1, diperoleh 81 siswa $(79,4 \%)$ berpendapat ketika bus berhenti, Amir mendapatkan dorongan ke depan oleh bus. Setelah dilakukan wawancara, siswa mengaitkan soal tersebut pada saat menaiki bus dan beranggapan ketika bus berhenti mendadak, tubuh mereka seolah-olah ada yang mendorong ke depan. Sehingga mereka langsung mengambil kesimpulan bahwa bus melakukan dorongan kepada tubuh mereka dan mereka meninjau gerak siswa dan bus dari bumi sebagai kerangka acuan. Hal 
tersebut sesuai dengan pernyataan (Docktor \& Mestre, 2014) sebagian pengetahuan yang dimiliki oleh siswa merupakan pengetahuan yang berasal dari pengalaman terhadap lingkungan, namun pengalaman tersebut masih berupa potongan-potongan yang belum menjadi pengetahuan yang utuh. Sehingga membutuhkan proses berpikir untuk membangun pengetahuan yang dapat digunakan untuk menjelaskan suatu konsep.

Berdasarkan hasil penelitian menunjukkan siswa masih memiliki pemahaman yang rendah pada materi hukum I newton. Sebagian siswa masih mengalami kesulitan dalam mengerjakan soal, siswa kesulitan dalam memahami makna fisis hukum I newton. Kemudian (Nurcahyo, Wartono, \& Yuliati, 2017) menyatakan kurang tepatnya pemahaman konsep berdampak pada kesulitan siswa dalam menyelesaikan permasalahan dalam Hukum Newton.

\section{Gaya pada Gerak Vertikal}

Dalam soal ini seorang anak yang melempar bola karet ke atas dan sampai sebelum bola karet menyentuh lantai. Kemudian siswa ditanya gaya yang bekerja pada bola karet selama di udara. Berdasarkan hasil jawaban siswa diperoleh 62 siswa $(60,8 \%)$ siswa menjawab gaya ke atas yang berkurang secara beraturan sampai titik tertinggi, kemudian ketika bola bergerak ke bawah gaya gravitasi ke bawah bertambah secara beraturan. Setelah dilakukan wawancara, siswa masih beranggapan jika gerak bola diperlambat maka gaya gravitasinya juga diperlambat kemudian ada juga siswa berpendapat gaya yang dilakukan ke atas berlawanan dengan gaya gravitasi sehingga gayanya lama-kelamaan berkurang, sedangkan ketika jatuh bola bergerak ke bawah searah dengan gaya gravitasi sehingga gaya gravitasinya bertambah dan 39 siswa (38,2\%) siswa menjawab ketika bola naik hingga titik tertinggi, bekerja gaya pelempar ke atas yang berkurang secara beraturan dan gaya gravitasi yang hampir konstan. Ketika bola turun hingga mencapai tanah hanya bekerja gaya gravitasi yang hampir konstan. Siswa berpendapat ketika bola bergerak ke atas gaya pelemparnya masih tetap bekerja pada bola karena pengaruh lemparan awal, dan ketika turun ke bawah hanya bekerja pengaruh gravitasi yang besarnya konstan.

Berdasarkan hasil penelitian, banyak siswa yang masih memiliki kesalahan pada saat mengerjakan soal. Hal tersebut menunjukkan siswa masih memiliki pemahaman yang rendah. Siswa kesulitan dalam memahami makna fisis Hukum Newton dan belum terlatih dalam mengidentifikasi gerak gaya vertikal. Siswa masih kesulitan dalam identifikasi gaya yang bekerja pada benda (Nun Shiha, 2014). Kemudian (Maries \& Singh, 2013) juga menjelaskan mengidentifikasi gaya pada benda dapat mempermudah menyelesaikan permasalahan.

\section{Hukum III Newton}

Dalam soal Hukum III Newton, mobil sedan bergerak dipercepat sedang menarik truk yang sedang mogok, kemudian siswa ditanya besar gaya interaksi pada saat sedan menarik truk. Berdasarkan hasil jawaban siswa, diperoleh 19 siswa (18,6 \%) menjawab gaya tarik oleh sedan kepada truk lebih kecil daripada gaya tarik truk kepada sedan. Siswa berpendapat gaya tarik sedan kepada truk lebih kecil. Kemudian setelah dilakukan wawancara, siswa berpikir karena massa truk lebih berat daripada masa sedan maka gaya yang dilakukan oleh truk lebih besar. Hal tersebut sesuai dengan penelitian (Narjaikaew, 2013) pada hukum III Newton, siswa beranggapan apabila semakin besar massa benda maka benda tersebut memiliki gaya yang semakin besar pula. Kemudian sebanyak 52 siswa (51\%) menjawab gaya tarik oleh sedan kepada truk lebih besar dari gaya tarik truk kepada sedan. Setelah dilakukan wawancara siswa berpendapat sedan sedang menarik truk yang bermuatan lebih besar dari sedan sehingga untuk dapat menggerakkan truk, sedan harus menarik dengan gaya yang lebih besar. dan sebanyak 25 siswa (24,5 \%) berpendapat truk tidak memberikan gaya kepada sedan. Siswa berpendapat pada saat sedan menarik truk, sedan yang memberikan tenaga kepada truk, sedangkan truk tidak memberikan gaya sama sekali.

Berdasarkan hasil penelitian, banyak siswa yang masih memiliki kesalahan pada saat mengerjakan soal. Hal tersebut menunjukkan siswa masih memiliki pemahaman yang rendah pada materi Hukum III Newton. Menurut (Jayanti, Wartono, \& Sutopo, 2016) siswa masih belum memahami gaya aksi-reaksi walaupun telah diajarkan materi Hukum III Newton. Kemudian menurut (Nun Shiha, 2014) perlunya perbaikan penerapan konsep Hukum Newton dalam kehidupan sehari-hari.

\section{SIMPULAN}

Penelitian ini menunjukkan siswa masih kesulitan dalam memahami materi hukum newton. Hal ini ditunjukkan dari hasil jawaban benar pada soal cukup rendah. Secara umum, pada materi Hukum Newton siswa masih kesulitan dalam memaknai secara fisis hukum I Newton, siswa hanya menghafalkan bunyinya. Kemudian, siswa kesulitan dalam menguraikan gaya yang bekerja pada suatu benda. Serta siswa beranggapan massa benda berpengaruh terhadap besar gaya aksi-reaksi dan siswa masih kesulitan dalam mengaplikasikan gaya aksi-reaksi antara dua benda pada kehidupan sehari-hari.

Dari hasil penelitian, disarankan untuk melakukan penelitian lebih lanjut dengan menerapkan pembelajaran multipel representasi. Hal tersebut dikarenakan dalam pembelajaran multipel representasi siswa tidak hanya belajar dalam bentuk matematis, melainkan dalam bentuk verbal, gambar maupun grafik. Diharapkan dengan pembelajaran berbagai representasi siswa diharapkan lebih memahami konsep Hukum Newton. 


\section{DAFTAR RUJUKAN}

Astrina, S., Sahala., \& Oktavianty, E. (2014). Remediasi Miskonsepsi Siswa pada Materi Hukum Newton menggunakan Jigsaw Berbantuan Booklet Kelas VIII SMP. Jurnal Pendidikan dan Pembelajaran, 3(1).

Docktor, J. L., \& Mestre, J. P. (2014). Synthesis of Discipline-Based Education Research in Physics. Physical Review Special Topics-Physics Education Research, 10(2), 020119.

Elmehdi, H., Pistorius, S., \& Suleiman, B. M. (2013). Difficulties Faced by College Students in Introductory Physics. A Case Study. Journal of Physic Education, 29(1), 7.

Heckler, A. F. (2010). Some Consequences of Prompting Novice Physics Students to Construct Force Diagrams. International Journal of Science Education, 32(14), 1829-1851.

Jayanti, I. B. R., Wartono., \& Sutopo. (2016). Dampak Program Resitasi terhadap Perubahan Konseptual Mahasiswa pada Topik Hukum III Newton. Jurnal Pendidikan: Teori, Penelitian, dan Pengembangan, 1(2), 256-264.

Kaddari, F., Elachqar, A., \& Alami, A. (2014). Teaching/Learning Mechanics in High School with the Help of Dynamic Software. Procedia-Social and Behavioral Sciences, 116, 4617-4621.

Kim, E., \& Pak, S.-J. (2002). Students do not Overcome Conceptual Difficulties after Solving 1000 Traditional Problems. American Journal of Physics, 70(7), 759-765.

Maries, A., \& Singh, C. (2013). To Use or Not to Use Diagrams: The Effect of Drawing a Diagram in Solving Introductory Physics Problems. 282. https://doi.org/10.1063/1.4789707

Narjaikaew, P. (2013). Alternative Conceptions of Primary School Teachers of Science about Force and Motion. ProcediaSocial and Behavioral Sciences, 88, 250-257.

Nun Shiha, S. (2014). Pengembangan Alat Peraga Percepatan Benda untuk Menunjang Pembelajaran Fisika pada Materi Hukum Newton tentang Gerak. Inovasi Pendidikan Fisika, 3(2).

Nurcahyo, A. W., Wartono., \& Yuliati, L. (2017). Kemampuan Pemecahan Masalah Hukum Gerak Newton Mahasiswa melalui Pembelajaran Cooperative Problem Solving. Jurnal Pendidikan: Teori, Penelitian, dan Pengembangan, 2(7), 963-970.

Palmer, D. (2001). Students' Alternative Conceptions and Scientifically Acceptable Conceptions about Gravity. International Journal of Science Education, 23(7), 691-706.

Rosenblatt, R., \& Heckler, A. F. (2011). Systematic Study of Student Understanding of the Relationships Between the Directions of Force, Velocity, and Acceleration in One Dimension. Physical Review Special Topics-Physics Education Research, 7(2), 20112.

Rosengrant, D., Van Heuvelen, A., \& Etkina, E. (2009). Do Students Use and Understand Free-Body Diagrams? Physical Review Special Topics - Physics Education Research, 5(1), 1-13. https://doi.org/10.1103/PhysRevSTPER.5.010108

Savinainen, A., Mäkynen, A., Nieminen, P., \& Viiri, J. (2012). An Intervention Using an Interaction Diagram for Teaching Newton's Third Law in Upper Secondary School. Physics Alive. Proceedings of the GIREP-EPEC 2011 Conference, $123-128$.

Savinainen, A., Mäkynen, A., Nieminen, P., \& Viiri, J. (2013). Does Using a Visual-Representation Tool Foster Students' Ability to Identify Forces and Construct Free-Body Diagrams? Physical Review Special Topics-Physics Education Research, 9(1), 10104.

Savinainen, A., \& Scott, P. (2002). The Force Concept Inventory: A Tool for Monitoring Student Learning. Physics Education, $37(1), 45$.

Sayre, E. C., Franklin, S. V, Dymek, S., Clark, J., \& Sun, Y. (2012). Learning, Retention, and Forgetting of Newton's Third Law Throughout University Physics. Physical Review Special Topics-Physics Education Research, 8(1), 10116.

Serway., \& Jewett. (2006). Physics for Scientists and Engineers. In Journal of College Science Teaching (Vol. 36). https://doi.org/013613923X

Singh, C., \& Schunn, C. D. (2016). Connecting Three Pivotal Concepts in K-12 Science State Standards and Maps of Conceptual Growth to Research in Physics Education. ArXiv Preprint ArXiv:1603.06024.

Smith, T. I., \& Wittmann, M. C. (2007). Comparing Three Methods for Teaching Newton's Third Law. Physical Review Special Topics-Physics Education Research, 3(2), 20105. 